\title{
Water Quality Assessment in Piracicamirim Creek Upstream and Downstream a Sugar and Ethanol Industry Through Toxicity Tests With Cladocerans
}

\author{
Rafael Grossi Botelho ${ }^{1 *}$, Luís Machado Neto ${ }^{1}$, Ricardo Alves de Olinda ${ }^{2}$, Carlos Tadeu \\ Dias $^{3}$ and Valdemar Luiz Tornisielo ${ }^{1}$ \\ ${ }^{1}$ Centro de Energia Nuclear na Agricultura; Universidade de São Paulo; Laboratorio de Ecotoxicologia Aquática; \\ 13416-000; Piracicaba - SP - Brasil. ${ }^{2}$ Departamento de Estatística; Centro de Ciências e Tecnologia; Universidade \\ Estadual da Paraíba; Av. das Baraúnas 351, Campus Universitário - Bodocongó; 58101-001; Campina Grande- \\ PB - Brasil. ${ }^{3}$ Departamento de Ciências Exatas; Escola Superior de Agricultura "Luiz de Queiroz; Universidade de \\ São Paulo; 13418-900; Piracicaba - SP - Brasil
}

\begin{abstract}
An environmental impact study was conducted to determine the Piracicamirim's creek water quality in order to assess the influence of effluents from a sugar industry in this water body. For this, toxicity tests were performed with a water sample upstream and downstream the industry using the microcrustaceans Daphnia magna, Ceriodaphnia dubia and Ceriodaphnia silvestrii as test organisms, as well as physical and chemical analysis of water. Results showed that physical and chemical parameters did not change during the sampling period, except for the dissolved oxygen. No toxicity was observed for $\mathrm{D}$. magna and reproduction of $\mathrm{C}$. dubia and $\mathrm{C}$. silvestrii in both sampling points. Thus, the industry was not negatively impacting the quality of this water body.
\end{abstract}

Key words: Daphnia magna, Ceriodaphnia dubia, Ceriodaphnia silvestrii, water quality

\section{INTRODUCTION}

Pollution of aquatic environments by the industrial and municipal wastewater has been a growing problem in many countries (Wang and Freemark 1995). In Brazil, the sugarcane sector plays an important role in the development of the country, since it is the largest sugarcane producer. Effluents discharged by this sector can produce changes in both aquatic fauna and flora, besides endangering the human health who use river water for domestic and agricultural purposes (Ayyasamy 2008). As regards the negative impact of industrial wastewater in aquatic environments, physical and chemical parameters are insufficient to assess the damage in this environment (Dalzell 2001). It is, therefore, essential to use the biological systems on toxicity tests using the living organisms since they interact with the pollutants, thus giving an effective response on the water quality (Wang and Freemark 1995; Gibson et al. 2000). Therefore, given the importance of both the methods, Cairns (2002) emphasized that there must be an association between the physical/chemical and biological monitoring, thus allowing a better assessment of the water pollution.

Studies have shown that the industrial discharges despite meeting the criteria and regulations established based on the physico-chemical and microbiological parameters exhibit high toxicity to

*Author for correspondence: rbotelho@cena.usp.br 
aquatic biota (Sotero-Santos et al. 2005). In order to evaluate such toxicity, ecotoxicological tests are used, since they are able to evaluate the toxicity of substances or mixtures, such as industrial effluent (Eckenfelder 2000).

Microcrustaceans are commonly used in toxicity tests because they have high sensitivity, availability and abundance, knowledge of their biology and ease of cultivation in the laboratory (Rand and Petrocelli 1985).

As the use of organisms at the same or different trophic levels may have different results for the toxicity (Chapman 2000), the objective of this work was to evaluate the Piracicamirim's creek water quality upstream and downstream which has discharge from an ethanol industry for physicochemical and ecotoxicological tests with $D$. magna, C. dubia and C. silvestrii.

\section{MATERIALS AND METHODS}

\section{Characterization of study area}

Piracicamirim creek is a tributary of the Piracicaba River and its watershed spans an area of $133 \mathrm{~km}^{2}$ (Ometto et al. 2000). Climate is subtropical and the meteorological characteristics define a rainy season (October to March) and a dry season (April to September) (Ometto et al. 2000; Silveira et al. 2000). Located in the municipalities of Piracicaba, Rio das Pedras and Saltinho, the Piracicamirim creek has $24.6 \mathrm{~km}$ length from its source (located in Saltinho-SP) to its mouth in the Piracicaba River. It is $4.26 \mathrm{~m}$ wide and has $1.56 \mathrm{~m}$ depth on average (Ometto et al. 2000). Currently, this watercourse is considered polluted, even after the construction of a sewage treatment plant in 1997 due to illegal sewage spills and chemical discharges of sugar cane crops (Ometto et al. 2004).

\section{Sampling stations, methods of collection and preservation}

Surface water samples were collected upstream and downstream an ethanol industry in the municipality of Rio das Pedras-SP. Samples were collected monthly from April to November 2010, during the harvest period. The collected water was stored in appropriate containers, identified, placed in polystyrene boxes with ice and taken to the laboratory. Physical and chemical parameters evaluated at each sampling included $\mathrm{pH}$, conductivity, dissolved oxygen, water temperature and room temperature.

\section{Acute toxicity test with $D$. magna}

Organisms used in the test (6-24 $\mathrm{h}$ old) were obtained from the cultures performed in the laboratory at $20 \pm 2^{\circ} \mathrm{C}$ and $16 \mathrm{~h}: 8 \mathrm{~h}$ photoperiod (light: dark). Reconstituted water with conductivity less than $10 \mu \mathrm{S} / \mathrm{cm}-1$ was used for the medium (medium M4) developed by Elendt and Bias (1990), prepared from the purified water plus salts, with $250 \pm 25 \mathrm{mg} / \mathrm{L} \mathrm{CaCO}_{3}$ total hardness and $7-8 \mathrm{pH}$ and with $300 \pm 25 \mu \mathrm{S} / \mathrm{cm}-1$ conductivity. Algae Pseudokirchneriella subcapitata were provided for feeding (3 x 105 cells/mL).

The acute toxicity test was done following the ABNT standard (2004). Samples were processed at the following dilutions: $100 \%$ (1:1), $50 \%$ (1:2) and $33.34 \%$ (1:3), using the medium M4 as dilution water according to Table 1 . At each dilution 10 neonates were added using two replicates. Test duration was $48 \mathrm{~h}$ in the dark, without food at $20^{\circ} \mathrm{C} \pm 2$. Results of effects observed for D. magna were expressed as toxicity factor (TF) that corresponded to the lowest dilution, which occurred immobility or up to $10 \%$ death. The result was expressed in integer equivalent to the test solution's dilution factor (Knie and Lopes 2004).

Table 1 - Sample dilution factor for acute toxicity test $(48 \mathrm{~h})$ with Daphnia magna.

\begin{tabular}{cccccc}
\hline Sample Dilution & $\begin{array}{c}\text { Dilution Factor } \\
(\text { FD) }\end{array}$ & Sample $(\mathbf{m L})$ & $\begin{array}{c}\text { Dilution Water } \\
(\mathbf{m L})\end{array}$ & $\begin{array}{c}\text { Final } \\
\text { Volume }(\mathbf{m L})\end{array}$ & $\begin{array}{c}\text { Test Solution } \\
\text { Concentration } \\
(\boldsymbol{\%})\end{array}$ \\
\hline Control & - & - & 50 & 50 & - \\
$1: 1$ & 1 & 50 & - & 50 & 100 \\
$1: 2$ & 2 & 25 & 25 & 50 & 50 \\
$1: 3$ & 3 & 16.67 & 33.33 & 50 & 33.33 \\
\hline
\end{tabular}


Toxicity tests with $C$.dubia and $C$. silvestrii To maintain the growth of $C$. dubia and $C$ silvestrii ABNT (2005) protocols were followed. Organisms were kept in the glass bottles containing $500 \mathrm{~mL}$ MS medium (Keating 1985) and 40 adult organisms in each culture. They were placed in incubator at $25^{\circ} \mathrm{C} \pm 2,16 \mathrm{~h}$ light and $8 \mathrm{~h}$ dark period. The culture medium was renewed twice a week. P. subcapitata was provided for feeding (approximately $1 \times 10^{5}$ cells per organism) three times a week. To implement the chronic toxicity test, the ABNT standards (2005) were followed. For each sampling point (upstream and downstream), $15 \mathrm{~mL}$ sample in its natural concentration $(100 \%)$ was added to the containers of $20 \mathrm{~mL}$ capacity. A control group with MS medium was also used. Each point and the control contained 10 repetitions and one organism aged between 6 to $24 \mathrm{~h}$ at each replicate. The test duration was 7 days and solutions were renewed every 2 days. The test was conducted in an incubator at $25^{\circ} \mathrm{C} \pm 2,16 \mathrm{~h}$ light and $8 \mathrm{~h}$ dark photoperiod. $P$. subcapitata was provided for feeding. At each renewal and end of the test, the adult organism was transferred to another container of equal volume and the number of born neonates was counted at each replicate.

\section{Statistical analysis}

Data obtained for C.dubia and C. silvestrii were analyzed by ANOVA followed by Tukey test with $\alpha=0.05$.

\section{RESULTS AND DISCUSSION}

Among the physical and chemical parameters analyzed, $\mathrm{pH}$ was the one which had minor variation over the sampling period, both upstream (5\%) and downstream (1\%), followed by the conductivity, air and water temperatures and final dissolved oxygen, which had a larger variation (Table 2).

Table 2 - Physical and chemical variables (means, standard deviation and coefficient of variation) of water upstream (A) and downstream (B) an sugar and ethanol industry from April to November 2010.

\begin{tabular}{llccc}
\hline A & Parameters & Mean & Standart Deviation & Coefficient of Variation (\%) \\
\hline & Water temperature & 17.90 & \pm 3.37 & 18 \\
& Air Temperature & 25.91 & \pm 4.25 & 16 \\
& pH & 6.84 & \pm 0.39 & 5 \\
& Conductivity & 96.45 & \pm 12.25 & 35 \\
& Dissolved Oxygen & 5.13 & \pm 1.81 & \\
\hline B & Parameters & Mean & Standart Deviation & Coefficient of Variation (\%) \\
\hline & Water temperature & 21.34 & \pm 2.58 & 12 \\
& Air Temperature & 27.80 & \pm 4.87 & 1 \\
& pH & 6.89 & \pm 0.07 & 12 \\
& Conductivity & 155.33 & \pm 18.70 & 26 \\
& Dissolved Oxygen & 5.68 & &
\end{tabular}

For the toxicity test with D. magna, no acute effect on mobility was observed in all the tested dilutions of the water samples upstream and downstream from April to November 2010. Thus, the toxicity factor value for D. magna obtained for all the samples was equal to 1 , meaning that there was no toxicity even in the pure sample.

About the chronic toxicity test with $C$. dubia, only the reproduction values in the control and downstream were statistically equal in every month (capital letters) (Table 3). Upstream, the average number of reproduction was statistically the same from April to October 2010 and different in November 2010 (capital letters) (Table 3).

For $C$. silvestrii, only the number of control's neonates was statistically equal during the months analyzed (capital letters) (Table 4). Upstream, the reproduction values observed were statistically equal from April to September 2010, differing in October and November 2010. However, the average reproduction in these two months was equal to those in April, July, August and September (capital letters) (Table 4). Downstream, April, May, June, July, September, October and 
November had the same average reproduction, differing only in August, which was statistically equal to May, July, October and November (capital letters) (Table 4).

Analyzing at each sampling site plus the control month after month (lowercase), it was clear that the control, upstream and downstream were statistically equal for $C$. dubia between April and October 2010 (Table 3), whereas the reproduction in the control and downstream were statistically identical for $C$. silvestrii in April, May, July, September and November (Table 4).
Analyzing at each sampling site plus the control month after month (lowercase), it was clear that the control, upstream and downstream were statistically equal for $C$. dubia between April and October 2010 (Table 3), whereas the reproduction in the control and downstream were statistically identical for $C$. silvestrii in April, May, July, September and November (Table 4).

Tables 3 and 4 , show the results water toxicity upstream; Tables show the same for downstream for $C$. dubia and $C$. silvestrii, respectively.

Table 3 - Average number of $C$. dubia neonates after 7 days of exposure to Piracicamirim's creek water (PiracicabaSP) upstream and downstream an sugar and ethanol industry.

\begin{tabular}{ccccccccc}
\hline TRE & APR & MAY & JUN & \multicolumn{1}{c}{ JUL } & AUG & SEP & OCT & NOV \\
\hline C & $15.30 \mathrm{aA}$ & $15.10 \mathrm{aA}$ & $15.00 \mathrm{aA}$ & $15.20 \mathrm{aA}$ & $15.70 \mathrm{aA}$ & $15.30 \mathrm{aA}$ & $15.80 \mathrm{aA}$ & $15.00 \mathrm{aA}$ \\
$\mathrm{U}$ & $20.00 \mathrm{aA}$ & $14.10 \mathrm{aA}$ & $16.60 \mathrm{aA}$ & $11.40 \mathrm{aAB}$ & $14.20 \mathrm{aA}$ & $8.50 \mathrm{aAB}$ & $9.10 \mathrm{aAB}$ & $0.90 \mathrm{bB}$ \\
$\mathrm{D}$ & $10.80 \mathrm{aA}$ & $19.10 \mathrm{aA}$ & $16.00 \mathrm{aA}$ & $19.10 \mathrm{aA}$ & $17.40 \mathrm{aA}$ & $12.00 \mathrm{aA}$ & $20.20 \mathrm{aA}$ & $14.40 \mathrm{aA}$ \\
\hline
\end{tabular}

$\mathrm{C}=$ Control, $\mathrm{U}=$ Upstream, $\mathrm{D}=$ Downstream. Means followed by the same letters do not differ by Tukey test with $\alpha=0.05$.

Table 4 - Average number of $C$. silvestrii neonates 7 days after exposure to Piracicamirim's creek water (Piracicaba-SP) upstream and downstream an sugar and ethanol industry.

\begin{tabular}{ccccccccl}
\hline TRE & APR & MAY & JUN & JUL & AUG & \multicolumn{1}{c}{ SEP } & OCT & \multicolumn{1}{c}{ NOV } \\
\hline C & $15.40 \mathrm{aA}$ & $18.20 \mathrm{aA}$ & $21.40 \mathrm{aA}$ & $19.20 \mathrm{aA}$ & $16.20 \mathrm{aA}$ & $15.70 \mathrm{abA}$ & $15.00 \mathrm{abA}$ & $15.80 \mathrm{aA}$ \\
$\mathrm{U}$ & $17.70 \mathrm{aA}$ & $23.30 \mathrm{aA}$ & $21.40 \mathrm{aA}$ & $14.50 \mathrm{aAB}$ & $13.80 \mathrm{bAB}$ & $11.50 \mathrm{aAB}$ & $7.50 \mathrm{bB}$ & $7.50 \mathrm{aB}$ \\
$\mathrm{D}$ & $12.20 \mathrm{aB}$ & $18.50 \mathrm{aAB}$ & $4.50 \mathrm{bB}$ & $23.80 \mathrm{aAB}$ & $29.70 \mathrm{aA}$ & $11.20 \mathrm{aB}$ & $22.90 \mathrm{aAB}$ & $17.90 \mathrm{aAB}$ \\
\hline \multicolumn{7}{c}{ C = Control, U = Upstream, D = Downstream. Means followed by the same letters do not differ by Tukey test with $\alpha=0.05}$.
\end{tabular}

Table 5 - Comparison of toxicity tests results with $C$. dubia from the water sample collected upstream and downstream an sugar and ethanol industry from April to November 2010 compared to the control.

\begin{tabular}{ccccccccc}
\hline T & APR & MAY & JUN & JUL & AUG & SEP & OCT & NOV \\
\hline U & NT & NT & NT & NT & NT & NT & NT & TO \\
D & NT & NT & NT & NT & NT & NT & NT & NT \\
\hline
\end{tabular}

$\mathrm{T}=$ Treatment, $\mathrm{U}=$ Upstream, $\mathrm{D}=$ Downstream.

$\mathrm{TO}=$ Toxic, $\mathrm{NT}=$ Non Toxic.

Table 6 - Comparison of toxicity tests results with C.silvestrii from the water sample collected upstream and downstream an sugar and ethanol industry from April to November 2010 compared to the control.

\begin{tabular}{ccccccccc}
\hline T & APR & MAY & JUN & JUL & AUG & SEP & OCT & NOV \\
\hline U & NT & NT & NT & NT & TO & NT & TO & TO \\
D & NT & NT & TO & NT & NT & NT & NT & NT \\
\hline
\end{tabular}

$\mathrm{T}=$ Treatment, $\mathrm{U}=$ Upstream, $\mathrm{D}=$ Downstream.

$\mathrm{TO}=$ Toxic, $\mathrm{NT}=$ Non Toxic.

Cladocerans, especially daphnids, are widely used as test organisms in ecotoxicological studies, and its known sensitivity is certainly one of the reasons for its acceptance (Viganò et al. 1996). Several studies have compared the sensitivity of these organisms with other groups of aquatic organisms
(Viganò et al. 1996). Overall, it has been observed that daphnids have a similar sensitivity to toxic substances (Mount and Norberg 1984; Kline et al. 1989) and C. dubia is sometimes more sensitive than the D. magna (Winner 1988; Mokry and Hoagland 1990; Kszos et al. 1992). 
The toxicity of a river whose basin is heavily industrialized and urbanized can be caused by many unknown contaminants (Viganò et al. 1996). Although toxicity tests could not provide information of probable toxicants present in the environment, Kimerle et al. (1985), using this type of test with at least two different species, reported reliable results in relation to the danger of toxic substances in the environment.

Concerning the physical and chemical analyses of water, comparing the parameters of both the sampling sitess no change was observed. There was no toxic effect of water for D. magna, $C$. dubia and $C$. silvestrii, showing that the three species had similar sensitivities in relation to water of the sampling points.

Several studies have reported the influence of industrial discharges on water quality and aquatic organisms. For example, Knie and Lopes (2004) reported the quality of effluents from the pharmaceutical, textile, metallurgical, electroplating and drinks industries and observed a 64 toxicity factor for the $V$. ficheri in the textile industry, while for the D. magna the same industry had toxicity factor equal to 16 , which proved the high toxicity of these effluents. According to these authors, when the result of acute toxicity presented toxicity factor value higher than one, sample had toxicity, but if this value was equal to 1 (as in this study) the sample was not toxic, since it was unnecessary to be diluted in order to not cause effect to the organisms. In another study, Nedeau et al. (2003) analyzed the water samples collected downstream an industrial effluent and it had negative effect on the benthic community. However, Gómez et al. (2008) evaluated the effect of effluents from a textile industry on the water quality and habitat through the benthic community. Results showed that the water after downstream the industry decreased species richness and abundance. Arimoro (2009) reported a drastic reduction of benthic macroinverbrate species after the discharge effluent of a rubber industry. Yadav et al. (2009) correlated the effect of effluents from the fertilizer industry with reduced levels of acetylcholinesterase from various organs of the fish species Channa striatus. Assessing the toxic effects of industrial effluents, Radic' et al. (2010) observed growth inhibition and chlorophyll levels in duckweed (Lemna L. minor). Liu et al. (2002) found that the effluent of an electroplating industry was highly toxic to Daphnia similis. Ayyasamy et al. (2008) evaluated the toxicity of effluents from a sugarcane industry on the terrestrial and aquatic plants, and observed that the concentrations above $60 \%$ affected the growth and there was decrease in the levels of chlorophyll, protein and carbohydrates with increasing concentrations.

Although no toxic effects was observed from the samples collected after the discharge of the effluent from the alcohol industry on D. magna, $C$. dubia and $C$. silvestrii, it would be necessary to give greater importance to long-term monitoring studies in aquatic environments near the industrial activity using the aquatic species as test organisms.

\section{CONCLUSION}

According to the results of physical and chemical parameters and acute toxicity tests with $D$. magna and chronic tests with $C$. dubia and $C$. silvestrii, the industry was not impacting this aquatic environment since most of the observed toxicity occurred upstream industry.

\section{ACKNOWLEDGEMENTS}

The authors thank the Fundação de Amparo à Pesquisa do Estado de São Paulo (FAPESP) for the financial support.

\section{REFERENCES}

ABNT. Associação Brasileira de Normas Técnicas. NBR 13373: ecotoxicologia aquática - toxicidade crônica - método de ensaio com Ceriodaphnia spp (Crustacea, Cladocera). Rio de Janeiro, 2005. 15 p.

Arimoro FO. Impact of rubber effluent discharges on the water quality and macroinvertebrate community assemblages in a forest stream in the Niger Delta. Chemosphere. 2009; 77: 440-449.

Ayyasamy PM, Yasodha R, Rajakumar S, Lakshmanaperumalsamy P, Rahman PKSM, Lee S. Impact of sugar factory effluent on the growth and biochemical characteristics of terrestrial and aquatic plants. Bull Environ Contam Toxicol. 2008; 81: 449454.

Cairns J Jr. Environmental monitoring for the preservation of global biodiversity: The role in sustainable use of the planet. Int J Sustain Dev World Ecol. 2012; 9:135-150. 
Chapman PM. Whole effluent toxicity testingusefulness, levels of protection, and risk assessment. Environ Toxicol Chem. 2002; 19: 3-13.

Dalzell DJ, Alte S, Aspichueta E, De la Sota A, Etxebarria J, Gutierrez M, Hoffmann CC, Sales D, Obst U, Christofi N. A comparison of five rapid direct toxicity assessment methods to determine toxicity of pollutants to activated sludge. Chemosphere. 2001; 47: 535-545.

Eckenfelder WW. Industrial water pollution control. Third Ed. New York, USA: Mc-Graw Hill International; 2000.

Gibson GR, Bowman ML, Gerritsen Snyder J, Stribling BD. Estuarine and Coastal Marine Waters: Bioassessment and Biocriteria Technical Guidance. EPA 822-B-00-024. U.S. Environmental Protection Agency, Office of Water, Washington, DC. 2000.

Gómez N, Sierra MV, Cortelezzi A, Rodrigues Capítulo A. Effects of discharges from the textile industry on the biotic integrity of benthic assemblages. Ecotoxicol Environ Saf. 2008; 69: 472-479.

Keating KI. A system of defined (sensu stricto) media for daphnid (Cladocera) culture. Water Res. 1985; 19: 73-78.

Kimerle RA, Werner AF, Adams WJ. Aquatic hazard evaluation principles applied to the development of water quality criteria. In: Cardwell RD, Purdy R, Bhaner RC. Aquatic Toxicology and Hazard Assessment: 7th Symposium, ASTM STP 854, American Society for Testing and Materials, Philadelphia. 1985. pp. 538-547.

Kline ER, Jarvinen AW, Knuth M L. Acute toxicity of triphenyltin hydroxide to three cladoceran species. Environmental Poll. 1989; 56: 11-17.

Knie JLW, Lopes EWB. Testes ecotoxicológicos: métodos, técnicas e aplicações. Florianópolis: FATMA/GTZ; 2004.

Kszos LA, Stewart AJ, Taylor PA. An evaluation of nickel toxicity to Ceriodaphnia dubia and Daphnia magna in a contaminated stream and in laboratory tests. Environ Toxicol Chem.1992; 11: 1001-1012.

Liu MC, Chen CM, Cheng HY, Chen HY, Su YC, Hung TY. Toxicity of different industrial effluents in Taiwan: a comparison of the sensitivity of Daphnia similis and Microtox. Environ Toxicol.2002; 17: 9397.

Mokry LE, Hoagland KD. Acute toxicities of five synthetic pyrethroid insecticides to Daphnia magna and Ceriodaphnia dubia. Environ Toxicol Chem. 1990; 9: 1045-1051.

Mount DI, Norberg TJ. A seven-day life cycle cladoceran toxicity test. Environ Toxicol Chem. 1984; 3: 425-434.
Nedeau EJ, Merrit RW, Kaufman MG. The effect of an industrial effluent on an urban stream benthic community: water quality vs. habitat quality. Environ Poll. 2003; 123: 1-13.

Ometto JPHB, Gessner A, Martinelli LA, Bernardes MC, Krusche AV, Camargo PB. Macroinvertebrates community as indicator of land-use changes in tropical watersheds, Southern Brazil. Ecohydrol Hydrobiol. 2004; 4: 35-47.

Ometto JPHB, Martinelli LA, Ballester MV, Gessner A, Krusche AV, Victoria RL, Williams, M. Effects of land use on water chemistry and macroinvertebrates in two streams of the Piracicaba river basin, Southeast Brazil. Freshwater Biol. 2000; 44: 327337.

Radic' S, Stipanicev D, Cvjetko P, Mikelic' I.L, Rajcic' MM, Sirac S, Pevalek-Kozlina B, Pavlica M. Ecotoxicological assessment of industrial effluent using duckweed (Lemna minor L.) as a test organism. Ecotoxicology. 2010; 19: 216-222.

Rand GM, Petrocelli SR. Fundamentals of aquatic toxicology: Methods and application. Washington DC: Hemisphere Publishing Corporation; 1985.

Silveira AM, Victoria RL, Ballester MV, Camargo PB, Martinelli LA, Piccolo MC. Simulação dos efeitos das mudanças do uso da terra na dinâmica de carbono no solo da bacia do rio Piracicaba. Pesq. agropec. bras. 2000; 35: 389-399.

Sotero-Santos RB, Rocha O, Povinelli, J. Evaluation of water treatment sludges toxicity using the Daphnia bioassay., Water Res. 2005; 39: 3909-3917.

Viganò L, Bassi A, Garino A. Toxicity evaluation of waters from a tributary of the river Po using the 7-day Ceriodaphnia dubia test. Ecotoxicol Environ Saf. 1996; 35: 199-208.

Wang W, Freemark K. The use of plants for environmental monitoring and assessment. Ecotoxicol Environ Saf. 1995; 30: 289-301.

Winner RW. Evaluation of relative sensitivities of 7-d Daphnia magna and Ceriodaphnia dubia toxicity tests for cadmium and sodium pentachlorophenate. Environ Toxicol Chem. 1988; 7: 153-159.

Yadav A, Gopesh A, Pandey RS, Rai DK, Sharma B. Acetylcholinesterase: a potential biochemical indicator for biomonitoring of fertilizer industry effluent toxicity in freshwater teleost, Channa striatus. Ecotoxicology. 2009; 18: 325-333.

Received: May 09, 2011; Revised: October 11, 2011; Accepted: May 07, 2012. 